\title{
SECULARISM AND BELIEF IN GEORGIA'S PANKISI GORGE
}

\author{
REBECCA GOULD \\ University of Iowa
}

'If one wants to write an anthropology of Islam one should begin, as Muslims do, from the concept of a discursive tradition that includes and relates itself to the founding texts of the Qur'a an and the Hadith. Islam is neither a distinctive social structure nor a heterogeneous collection of beliefs, artifacts, customs, and morals. It is a tradition. ${ }^{1}$ Thus Talal Asad, the preeminent anthropologist of secularism, stated over two decades ago in his influential discussion of the 'Idea of an Anthropology of Islam'. In spite of Asad's articulate critique of both the classical anthropological and Orientalist framing of Islam as an object of inquiry, his recommendations can hardly be said to have become normative among scholars of Islamic life-worlds, particularly in the present.

Our current distance from Asad's ideal may have to do with the difficulty of fulfilling the imperative he sets for students of that segment of contemporary societies which either defines itself, or may reasonably be defined as, Islamic: to begin with, the foundational texts within this tradition. For most working within this field, the Qur'ān and ḥadìth are likely to be the last rather than first set of conceptual resources they draw on in formulating the results of their research for Anglophone audiences. Another deeper complication entailed by Asad's prescription is its implicit advocacy of religion as a category that should motivate, rather than constrain, intellectual inquiry. Asad instructs us to begin with precepts that are in most social science contexts relegated to contextual background. Such an injunction poses a challenge in a secular age when reigning discourses contrast religion to reason, and regard belief as the incomplete representation of reality. It is certainly no accident that major

${ }^{1}$ Talal Asad, The Idea of an Anthropology of Islam (Washington, DC: Center for Contemporary Arab Studies, Georgetown University, 1986). Rather than marking a full break with the Orientalist tradition, Asad's anthropology of Islam builds on the Orientalist precedent of privileging the text as an axis of inquiry; an arguable distinction between these two approaches is that Asad proposes to subject the texts of European civilization to the same scrutiny that he subjects Islamic texts. 
critiques of secular knowledge in modernity have been issued almost unilaterally by those engaged with the Islamic world, ${ }^{2}$ for, unlike modern Christianity, Islam seems to pose the deepest challenge to secularizing points of view. The present essay probes these dichotomies-between religion and the secular on the one hand and Islam and Christianity on the other-on the basis of fieldwork among the Chechen Kists of Georgia's Pankisi Gorge, one of the oldest and largest Muslim communities in the Republic of Georgia. ${ }^{3}$ Until the influx of Chechen refugees from across the Caucasus mountains during the RussoCaucasian wars (1825-64), the Pankisi Gorge was largely Christian, though, from the sixteenth century onwards, populated more by Tushetians (known in the non-Georgian vernacular as Batsbi) with close ties to Muslim Chechens than by ethnic Georgians. At present, the Gorge is primarily inhabited by Muslim descendants of the Chechens who call themselves Kists and live on neighbourly terms with a sizeable minority of Georgian Christians. ${ }^{4}$ While many Kists subscribe to various secularisms that became normative in Soviet times, religious faith persists into the present, and at an unprecedented level.

In addition to decentring the commonly critiqued relation between European knowledge and the non-European subject, a renewed focus on the Islamic tradition (including by scholars who do not define themselves as Islamic) provides richer conceptual foundations for understanding our object of inquiry as compared to more familiar resources grounded in

2 Talal Asad, Formations of the Secular: Christianity, Islam, Modernity (Stanford: Stanford University Press, 2003); Gil Anidjar, 'Secularism', Critical Inquiry 33/1 (2006): 52-77; Saba Mahmood, 'Religious Reason and Secular Affect: An Incommensurable Divide?', Critical Inquiry, 35/4 (2009): 836-62. Asad, Anidjar, and Mahmood primarily focus on the impact of secularism on European perceptions of Islam.

${ }^{3}$ Other Muslim communities in Georgia include the Azeris centred in Marabdeli and the Daghestanis centred in the region called Satslis Xure (Sow's Ear), both in the northeasterly region of Kaxeti. The Azeris are more numerous than the Kists of Pankisi, but they have assimilated more fully into Georgian society than have the Kists.

${ }^{4}$ The dense and entangled history of Muslim and Christian settlements in the Pankisi Gorge is surveyed in Mat'e Albut'ashvili, Pankisis xeoba, (ed. G. and N. Javaxishvili; T'bilisi: K'art'ul kavkaziuri urt'iert'obis tsentri, 2005 [1898]); Rebecca Gould, 'Language Dreamers: Race and the Politics of Etymology in the Caucasus' in Bruce Grant and Lale Yalçın-Heckmann (eds.), Caucasus Paradigms: Anthropologies, Histories, and the Making of a World Area (Berlin: LIT, 2007), 143-66. Worth mentioning, though more political in focus, is Johannes Rau, Russland, Georgien, Tschetschenien: der Konflikt um das Pankisi-Tal (1997-2003): ein Handbuch (Berlin: Köster, 2005). 
liberal imaginaries, and better enables us to grasp the processes of change occurring within Islamic societies today. Noting the conceptual failings of 'a focus purely on "belief" and doctrines [...] with regard to the richness and complexity of religious life', Deweese has drawn attention to the imperative that scholars of Islamic societies move beyond the liberal binary of belief versus doubt and embrace a more richly grounded understanding of the many varieties of Islam that inform a Muslim's daily life. ${ }^{5}$ Although the tension between textuality and daily life is arguably intrinsic to the fieldwork scenario itself, examining contemporary Islamic societies from perspectives internal to the Islamic tradition helps us not only to view these societies differently, but to view modern European norms through illuminating, if unfamiliar, lenses.

Here I propose, on the basis of fieldwork in Pankisi conducted over the course of two years, to examine the contribution that specific modalities of Islamic belief and worship may make to our understandings of the meanings and paradoxes attending the multivalent calls for secularism across the globe. My ethnography is organized according to two aspects of Pankisi's landscape that have undergone transformations in the past decade: minarets and headstones. These two aesthetic dimensions in turn yield understanding of the role played by public worship and mourning in mediating social life in Pankisi. In addition to their importance as regulatory structures for daily life, they also reveal Pankisi's complex interaction with what we have come to call modernity and specifically with the elements of belief and doubt that enter into this experience.

Minarets first became a staple of the Islamic architecture during the Umayyad period (661-750), when the caliph al-Walīd (r. 705-715) adapted a Christian church in Damascus into an Islamic mosque. ${ }^{6}$ This long history of interchange between Islamic, Jewish, and Christian, and prior to that, Zoroastrian and Mesopotamian, modes of worship, has largely been forgotten in recent centuries, to the extent that the minaret has become, according to one recent articulation, an exclusively Islamic 'symbol of political-societal power claim of Islam', with such capacity to arouse fear in non-Muslims that the citizens of Switzerland recently approved an amendment to their constitution prohibiting the building of

${ }^{5}$ Devin DeWeese, 'Islam and the Legacy of Sovietology: A Review Essay of Yaacov Ro'i's Islam in the Soviet Union', Journal of Islamic Studies, 13/3 (2002): 298-330, at 303.

${ }^{6}$ Richard J. H. Gottheil, 'Origin and History of the Minaret', Journal of the American Oriental Society, 30/2 (1910): 132-54, at 138; Robert Hillenbrand, $E I^{2}$ art., 'Manāra, Manār', vi. 361-9. 
future minarets. ${ }^{7}$ Nor is it accidental that the first Islamic journal to propagate the post-madhhab (la-madhhabiyya, 'without schools of law') orientation of modernist Islam was called al-Manār. Founded by the reformer Muhammad 'Abduh in 1897 and later edited by 'Abduh's student Rashìd Rida until 1935, the journal was a major channel for the dissemination of ideas that are currently called Salafi. ${ }^{8}$

The recent law is the first such initiative in Europe since 1893 to isolate a single community for discrimination in an official—constitutional, and we might add, democratically constitutional—context. The 1893 initiative led to a law, still in effect, prohibiting kosher animal slaughter, intended to discourage immigration to Switzerland by Jews escaping the pogroms of Tsarist Russia. ${ }^{9}$ But it is not only in Switzerland that minarets have stirred controversy. Among Muslims living on Islamic peripheries, the minaret has come to represent more than itself; whether in austerity or luxury, it is understood to contain a prophecy about the place of Islam in the future commonwealth of nations.

Georgia's Pankisi Gorge was, until two decades ago, inhabited exclusively by Chechen-speaking Kists who had assimilated to Georgian ways by learning the Georgian language, adopting Georgia's history as part of their own sub-national narrative, and in all substantive ways-with the crucial exception of religion-becoming Georgian. A decade of war-time migration by Chechen refugees from across the mountainous border to the north has transformed the character of Pankisi's Islam. In the late nineteenth and early twentieth centuries, Islamic practice in Pankisi was marked by a steady convergence with Georgian-Christian styles of worship, even as the region itself was

7 Mark LeVine, 'In Fear of “Eurabia”?', Al Jazeera (3 December 2011), http:// english.aljazeera.net/focus/2009/12/20091229223658221.html [accessed 6 June 2011]. For a scholarly study of the validity of the minaret ban (written prior to the passage of the Swiss initiative), see Marcel Stüssi, 'Banning of Minarets: Addressing the Validity of a Controversial Swiss Popular Initiative', Religion and Human Rights, 3 (Brill, 2008): 135-53.

${ }^{8}$ On the contribution of journals such as al-Manār to Islamic modernism, see Stephen Sheehi, 'Arabic Literary-Scientific Journals: Precedence for Globalization and the Creation of Modernity', Comparative Studies of South Asia, Africa and the Middle East 25/2 (2005): 438-49.

9 Tariq Ramadan, 'My compatriots' vote to ban minarets is fueled by fear', Guardian (29 November 2009), www.guardian.co.uk/commentisfree/belief/ 2009/nov/29/swis-vote-ban-minarets-fear; Shlomo Avineri, 'What do mosque minarets and kosher slaughter have in common?' Haaretz (6 December 2009), www.haaretz.com/print-edition/opinion/what-do-mosque-minarets-and-kosherslaughter-have-in-common-1.2720. 


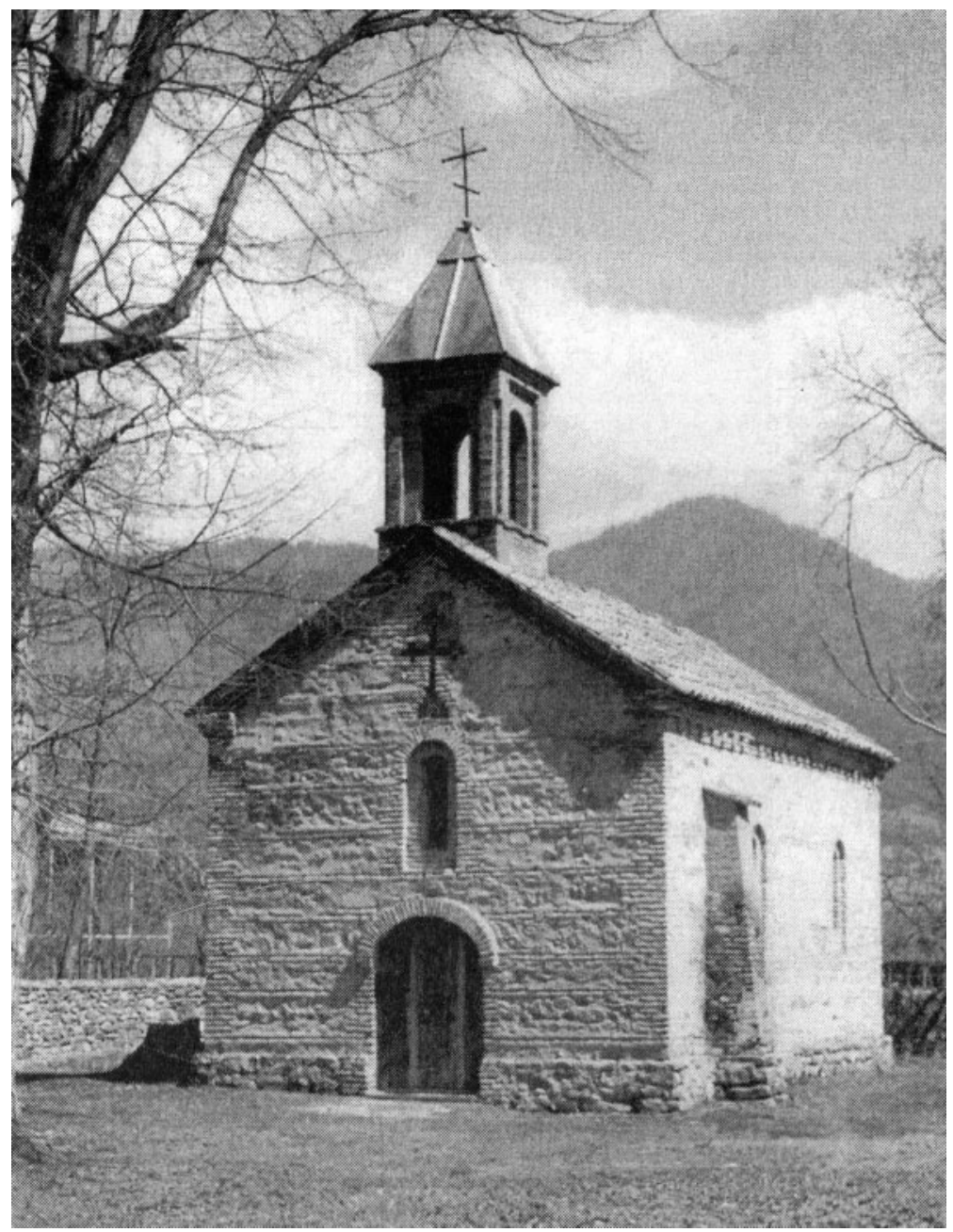

Fig. 1: St. Giorgi Church in Pankisi Gorge, village of Joqolo, built 1887.

marked by a symbiosis of these two traditions, as evidenced by the Church of St. Giorgi that stands in Joqolo, not far from the village of Duisi, where Pankisi's first minaret stands (Figs. 1 and 2). Both structures were built in the nineteenth century.

Subsequently, despite the indoctrination under Soviet rule into state-enforced atheism, recent years have seen a return to Islam. Although the Caucasus has been part of the Islamic world from the earliest days of the Umayyad caliphate, when Arab warriors converted 


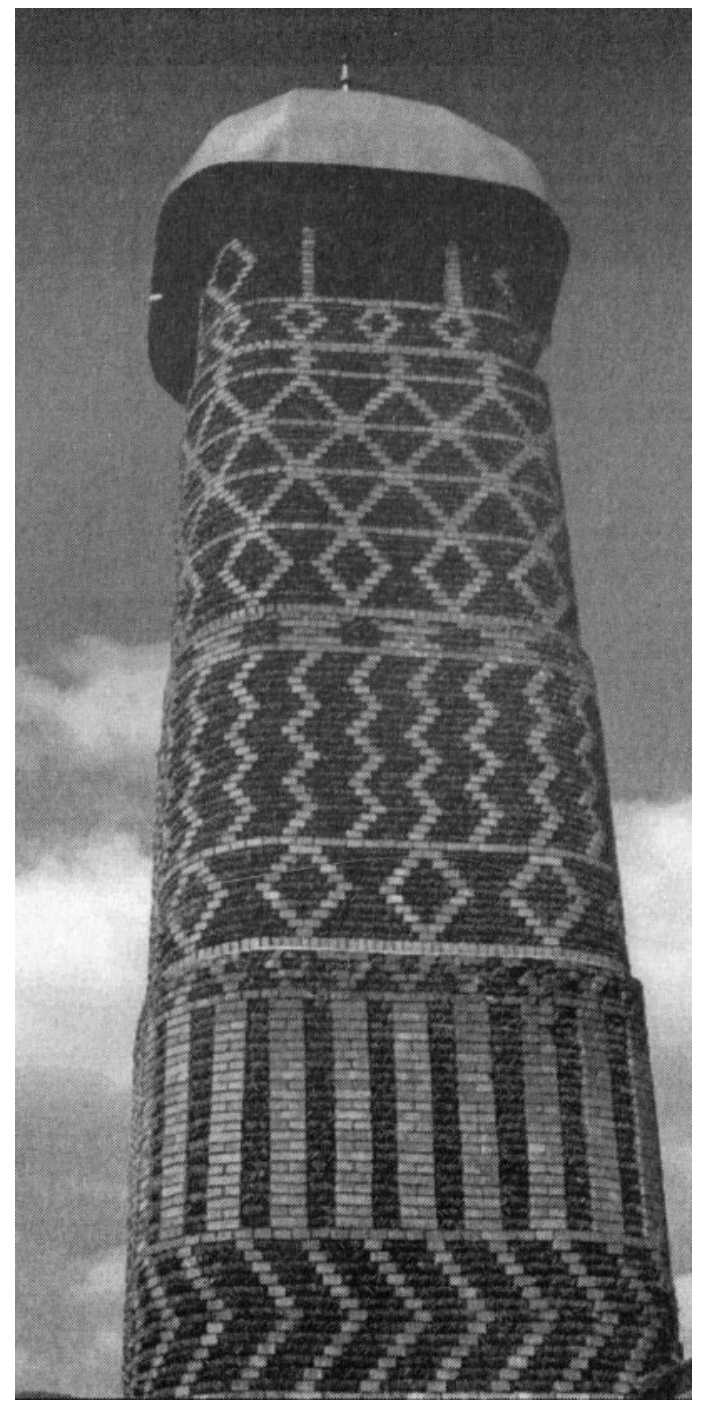

Fig. 2: The first minaret in Pankisi, in the village of Duisi, ca. 19th c. ${ }^{10}$

the Sassanid outpost of Derbent (currently the largest city in southern Daghestan, part of the Russian Federation) into an Umayyad fortress, two centuries of Russian imperial and subsequently Soviet rule have done

${ }^{10}$ Figs. 1 and 2, and 7 and 8 taken from Albut'ashvili, Pankisis xeoba, pp. 20, $28,17,19$, respectively. 
much to obscure the deep Islamic pasts of this region. ${ }^{11}$ But, in Pankisi as elsewhere, what has been lost at the level of public consciousness persists in the realms of myth, storytelling, burial, marriage, and birth customs, literature, folklore, and language. ${ }^{12}$ A survey of the history and ethnography of Pankisi demonstrates the region's startling capacity for assimilation: of Chechen to Georgian, Islamic to Christian, and Sunni to Shi'a. Recent decades have brought new influences and new strategies for assimilation.

Among these forms is one commonly referred to in the Russian press, everyday conversation, and in scholarship, under the moniker 'Wahhābī', a term that is especially inexact in view of the discontinuities between the Wahhabi and Salafi movement on the one hand and the Salafi movement and the new Pankisi Islam on the other. ${ }^{13}$ That the term Wahhabi rather than Salafi is used pejoratively by scholars and by the local press to describe revivalist Islam in the former Soviet Union indicates one of the many displacements Muslims face in this world region. ${ }^{14}$ Though both

${ }^{11}$ Daghestan represents something of an exception to this rule; see inter alia Pis'mennye pamiatniki Dagestana XVIII-XIX vv.: sbornik statei (eds. Kh. A. Omarov and A. R. Shikhsaidov; Makhachkala: Dagestanskii filial AN SSSR, 1989). Soviet scholarship foregrounded Islamic pasts when such foregrounding was necessary to construct a pre-revolutionary Islamic other.

${ }^{12}$ See Shorena Kurtsikidze and Vakhtang Chikovani, Ethnography and Folklore of the Georgia-Chechnya Border: Images, Customs, Myths and Folk Tales of the Peripheries (Munich: Lincom Europa, 2008), esp. 227-61; Xvt'iso Mamisimedishvili, Pankisi: tsarsuli da t'anamedroveoba [Pankisi: past and modernity] (T'bilisi: T'bilisis universitetis gamomtsemloba, 2008); Iu. Shavxelishvili, Kul'turno-etnicheskie vzaimootnosheniia mezhdu Gruziei $i$ Checheno-Ingushetiei $v$ XIX $i$ nach. XX v. kisty Pankisi [Cultural and ethnic relations between Georgia and Chechnya-Ingushetia among the Kists of Pankisi from the beginning of the nineteenth to the twentieth centuries], (T'bilisi: Metsniereba, 1990).

13 Two typical and symptomatic accounts are: A. A. Iarlykapov, Problema vakhkhabizma na Severnom Kavkaze [The problem of Wahhabism in the North Caucasus] (Moscow: RAN, 2000) and V. Kh. Akaev, Sufizm i vakhkhabizm na severnom Kavkaze [Sufism and Wahhabism in the North Caucasus] (Moscow: RAN, 1999). Also see the critical review of Kurtsikidze and Chikovani's Ethnography and Folklore of the Georgia-Chechnya Border by Paul Manning in Anthropology of East Europe Review, 28/1 (2010): 414-18, which highlights the impact of 'global terror' on local historiography.

${ }^{14}$ The majority of scholarship on Islam in the Caucasus continues to be written from a monolithically Russian perspective, or from a perspective confined to a statist approach to the study of political life. Exceptions include V. O. Bobrovnikov, Musulmane Severnogo Kavkaza: obychai, pravo, nasilie: ocherki po istorii i etnografii prava Nagornogo Daghestana [Muslims of the 
terms imperfectly encompass the variegated contemporary movements under which they are bracketed, 'Salafi', which literally refers to the forefathers (salaf al-șalibinin) in the Islamic tradition, is employed here in preference to 'Wahhabi', in part due to the latter's narrow application and clearer association with a particular form of state-affiliated Islam of Saudi provenance.

Though they bear little relation to their Hanbali counterparts in Saudi Arabia, ${ }^{15}$ practitioners of this new brand of Islam are widely regarded as instigators of a form of religious piety never practised before in the Caucasus, or at least not known since the days of Imām Shāmil (17971871), the last ruler to unite the northern Caucasus, to whom Kists trace their ancestors, under the banner of Islam, in the north Caucasus' Third Imamate (1825-49). The new Muslims are resented by the older generation, raised on Soviet ideologies that propagated the falsity of all religions, yet also conscious of the inadequacy of Soviet accounts of the sacred. Before proceeding to explore a few reactions to the new Islam in Pankisi and its complex ways of interacting with the forms of worship and belief that preceded it, it will be useful to consider the historical foundations of classical Wahhabism in relation to the classical Sufism of the Caucasus in order to discern where they converge and diverge.

Wahhabism has been called the 'single most arresting movement in the Islamic world' during the early modern period. ${ }^{16}$ Insofar as 'Abd al-Wahhāb (1703-92) claimed to access truths that none of his teachers had known, his teaching 'represented a clear break with the immediate past'. ${ }^{17}$ But like all breaks, and perhaps to an even greater extent than

North Caucasus: custom, law and violence: Sketches on the history and ethnography of law in mountainous Daghestan] (Moscow: Vostochnaia lit. RAN, 2002); and, most recently, Michael Kemper, Raoul Motika and Stefan Reichmuth (eds.), Islamic Education in the Soviet Union and Its Successor States (Routledge: London, 2009).

15 One difference between classical Wahhabism and the new Pankisi Islam is suggested by their differing attitudes towards the building of minarets. Robert Hillenbrand ('Manāra') notes that the Wahhabis 'avoid building minarets on the grounds that they are ostentatious and unnecessary', whereas the new Salafis of Pankisi are known for their erection of minarets in regions which had never before seen such structures.

${ }^{16}$ Michael Cook, 'On Islam and Comparative Intellectual History', International Institute for Asian Studies Newsletter, 43 (2007): 7-7. Also on eighteenth-century Wahhabism, see Khaled El-Rouayheb, 'Opening the Gate of Verification: The Forgotten Arab-Islamic Florescence of the 17th Century', International Journal of Middle East Studies, 38/2 (2006): 263-81.

17 'Abd al-Wahhāb is reported to have said to his biographer and disciple, 'Not one among my teachers knew [what I learned]; if any of the scholars of the 'Arid 
usual, this one relied on ancient precedents. Needless to say, it is inadvisable to compare the intellectual revolution that was largely textual, inaugurated by 'Abd al-Wahhāb, with a popular movement such as one finds in Pankisi's revivalist Islam. The basic sources of the Wahhabi movement were not known directly to anyone I came across in Pankisi. Had they been available, the texts would have had to surmount forbidding linguistic barriers that have yet to be crossed. Kists read Georgian, Chechen, and in some cases Russian; Arabic is not part of the Pankisi curriculum.

The Wahhabi movement and the proponents of the new Pankisi Islam share in common a reaction against past precedent, as well as to transformations in their geopolitical situations. Whereas Wahhabism provided the 'banner under which a new state and a new order arose in eastern Arabia' and therefore contained a significance that was 'not just intellectual' but was also 'political and military', ${ }^{18}$ Pankisi's new Islam has also emerged over the course of the past three decades in response to political and war-induced change. The new movement in both situations sought to impose on the fragmented religious identities created by Soviet secular ideology a new ideational unity. Though there may be political aspirations, as with the Wahhabi aspiration for greater political power at the level of the nation-state, whatever latent desires exist in this direction cannot be fulfilled under current conditions. Both the Wahhabi movement and the new Pankisi Islam demonstrate that there is a relation between religious orientation and political aspiration and that religion serves as a source of meaning in times of crisis.

Like the Wahhabi movement, the new generation of Pankisi Muslim Kists present their religiosity in terms that openly contest the life-ways of their elders. One observer of the $d a^{c} w a$ movement in contemporary Egypt observed during her fieldwork that 'age hierarchy is often reversed when young $d u^{\prime} \bar{a} t$ invoke higher moral authority and greater Islamic knowledge than their elders to criticize them for their lax religious lifestyles'. ${ }^{19}$ Likewise, among the Pankisi Kists, the younger generation influenced by Islam perceives itself to occupy a moral space superior to

['Abd al-Wahhāb's hometown] claims that he knew the meaning of 'Là ilāha illa Allāb', or the meaning of Islam, before this time, or maintains that any of his teachers knew it, he lies, fabricates, leads people astray, and falsely praises himself', Ibn Ghannam, Rawdat al-afkār, i. 189.12 (Bombay, 1337), cited in Michael Cook 'On the Origins of Wahhābism', Journal of the Royal Asiatic Society, 3/2 (1992): 191-202, at 202.

${ }^{18}$ Cook, 'On Islam and Comparative Intellectual History', 7.

19 Saba Mahmood, Politics of Piety: the Islamic Revival and the Feminist Subject (Princeton: Princeton University Press, 2005), 116 n. 57. 
elders who engage in practices prohibited by the Qur'ān. The new Pankisi Islam also shared with Wahhabism a commitment to austere forms of worship—as demonstrated by their distinctive minaret (Fig. 2), built of grey stone and topped by a metallic roof-and opposition to shirk, polytheism, or the wrongful association with others' gods. ${ }^{20}$ In the eighteenth-century Hijaz, as in twenty-first century Pankisi, and midnineteenth-century Daghestan under Imām Shāmil's Third Imamate (1824-59), purity in religion requires the rejection of extraneous traditions, accrued customs ('ádat), and a return to the original ways of the Islamic forefathers. ${ }^{21}$

One motivation for the eighteenth-century reaction against shirk in the Hijaz was to advocate a turn to the roots of Islamic monotheism and a rejection of tașawwuf (Sufism). For 'Abd al-Wahhāb, this ambition developed after he received a dream. Roughly around the year 1745, he is reported by his earliest biographer to have received a blessing (khayr) from God that contained a teaching hitherto unknown to the Islamic world: 'I sought learning (talabtu al-'ilm)', he recounted, 'yet... I did not know the meaning of [the first part of the shahada] "there is no god but God" [lā iläha illa Alläh], nor did I know the religion of Islam,. ${ }^{22}$ Prior to his dream, 'Abd al-Wahhāb's vision had been clouded by shirk, the worship of saints ('awlīy $\vec{a}$ ), and a prevalence of pagan worship, including domed tombs. ${ }^{23}$ For the new generation of Islamic monotheists in Pankisi as for the Wahhabis and Salafis, rejection of shirk implies a rejection of the customs of their elders, including especially drinking and milder forms of gambling. The new generation of Pankisi Muslims dress

${ }^{20}$ For a relevant discussion of shirk in the contemporary context, see Sayyid Quțb, Milestones (Indianapolis: American Trust Publications, 1990), ch. 3. Salafi arguments concerning shirk are often drawn from the Qur'ānic texts 34. 20-4, 35. 40, and 46. 4. For shirk in the context of classical Islam, see Muhammad Ibrahim Surty, The Qur'anic Concept of al-Shirk (Polytheism) (London: Ta Ha Publishers, 1990).

21 Two outstanding sources in the vast bibliography of scholarship on Shāmil's imamate that implicitly invoke contemporary parallels with Pankisi are Michael Kemper, Herrschaft, Recht und Islam in Daghestan von den Khanaten und Gemeindebünden zum Gihadstaat (Wiesbaden: Reichert, 2005), esp. 317-404 and M. S. Gadzhiev, G. Sh. Kaymarazov and A. P. Shikhsaidov, Islam $i$ islamskaia kultura $v$ Daghestane (Moscow: Vostochnaia Literatura, 2001).

${ }^{22}$ Ibn Ghannam, Raw da, i. 189.12; Cook, 'Origins of Wahhābism', 202. On the origins of the shahāda, see Arent Jan Wensinck, The Muslim Creed: its Genesis and Historical Development (London: Frank Cass, 1965), $17 \mathrm{ff}$.

${ }^{23}$ Henri Laoust, Essai sur les doctrines sociales et politiques de Taki-d-Dìn Ahmad b. Taimīya: canoniste hanbalite, né à Harran en 661/1262, mort à Damas en 728/1328 (Cairo: l'Institut Français d'Archéologie Orientale, 1939), 530. 
austerely, refrain from drinking and gambling, and spend their spare time reading the Qur'ān.

Unlike the Wahhabis and Salafis, however, the rejection of shirk among the new generation of Pankisi Muslims is crucially informed by their engagement with tașawwuf. Given the long history of Naqshbandiyya and Qādiriyya Sufism in the north Caucasus, no viable religious movement can position itself in opposition to Sufi beliefs or worship practices. The purist and anti-Sufistic movements that spread through the Islamic heartland in the modern period had little impact on the Caucasus. Even the most austere of north Caucasian Islamic leaders, Imām Shāmil, fashioned himself as a Sufi and found inspiration in Sufi teachings for his movement. There is no deep-rooted suspicion of Sufi practices among contemporary Pankisi Muslims and no sense that Sufis have diverged from the path of the Ahl al-Sunna wa-l-Jamā'a, as one finds elsewhere.

At the same time, north Caucasian Sufism is diverse and has been made to serve political, as well as quietist ends. ${ }^{24}$ As in Algeria, Sufi teachings have informed anti-colonial movements, although recent scholarship has questioned the extent of Sufi involvement in militant Algerian and Daghestani anti-colonial resistance. ${ }^{25}$ But even when historians do not agree on the formative role played by Sufi Islam in the anti-colonial movements of the nineteenth century, a striking difference between these contexts and more temporally proximate ones cannot be denied: neither in the Muslim Caucasus nor in colonial Algeria was there a perceived conflict between Sufism and militant Islam. In his recent overview of Islam in the former Soviet Union, Adeeb Khalid has written that Sunni orthodoxy in Central Asia 'rested on a synthesis of juridical Islam with Sufism' such that sharîa and tarīqa came to be seen as complementary rather than competing sources of authority. The overlap between these two Islamic traditions was so intense that 'all ulama had Sufi affiliations, and Sufism realigned itself to the norms of juridical Islam. Networks of scholarly and Sufi activity were indistinguishable from one another'. ${ }^{26}$ The Russian Islamist Bobrovnikov has sought to

24 The Qādiriyya țariqa has the deepest roots among the Vainakh (Chechens, Kists, Ingush); the Naqshbandiyya tariqa has the deepest roots among Daghestani Muslims.

25 Jean-Louis Triaud, La légende noire de la Sanûssiya: une confrérie musulmane sous le regard français (1840-1930), (Paris: Maison des Sciences de l'Homme, 1995) and Alexander Knysh, 'Sufism as an Explanatory Paradigm', Die Welt des Islams, 42/2 (2002): 139-73.

${ }^{26}$ Adeeb Khalid, Islam after Communism: Religion and Politics in Central Asia (Berkeley: University of California Press, 2007), 31. 
capture this seeming paradox of multiple Islams coexisting with and informing each other by coining the term 'militant Sufism' to describe the historical legacy of the Naqshbandiyya tariqa in the northern Caucasus. $^{27}$

The Naqshbandiyya tarīqa has been appropriated by north Caucasian political leaders including Imām Shāmil and Najm al-Dīn al-Hutsī (d. 1925). North Caucasian Sufi leaders committed to the strict application of Qur'ānic principles and teachings derived from hadith worked within norms they understood as Sufi. The relation between tașawwuf and mainstream Islam within the new Pankisi Islam could not differ more starkly from Salafi and Wahhabi attitudes, which have historically regarded tașawwuf with derision. If north Caucasian Islam has tended to engage deeply with Sufi tariqāt of varying persuasions, it does not follow that Sufi Islam as it developed in the north Caucasus bears no relation to the four-madhhab arrangement according to which Sunnism has conventionally organized itself since the tenth century. It is perhaps not coincidental that Ahmad b. Hanbal (d. 855), the founder of the school of law to which present-day Wahhabism is most indebted, advocated a political theory that intersects closely with that of Kunta Hājjī (d. 1862), the bringer of Qadiri Sufism to the Caucasus.

Whereas Naqshbandi Sufism has traditionally enjoined active resistance to unjust regimes, Ahmad b. Hanbal prescribed the opposite approach to dealing with political injustice: 'The Friday worship, the celebration of the legal feasts, and the pilgrimage [hajj], are observed with the authorities [sultān], even if they are not upright, just, and pious. Taxes [șadaqāt] are paid to commanders [umarà'], whether they deal justly or wickedly... Those to whom God had entrusted your affairs are to be followed... and not opposed by your sword... to keep aloof in civil war [fitna] is an old custom whose observance is obligatory. ${ }^{28}$ Ahmad b. Hanbal's political views merit consideration within the framework of his scepticism towards the claims of human reason. These views belong to any account of Qadiri Sufism's intellectual foundations, for the founder of this branch in the twelfth century was a Hanbali named 'Abd al-Qādir al-Jīlānī (d. 1167). ${ }^{29}$

${ }^{27}$ V. O. Bobrovnikov, 'Al-Azhar and Shari'a Courts in Twentieth-century Caucasus', Middle Eastern Studies, $37 / 4$ (2001): 1-24, at 2.

${ }^{28}$ Ibn Abī Ya' lā, Ṭabaqāt al-Hanābila (ed. Muhammad Hamīd al-Fiqīi Cairo: Mațba'at al-Sunna al-Muhammadiyya, 2 vols., 1371/1952), excerpted from i. 24-31. Emphasis added.

${ }^{29}$ On Ibn Hanbal's mystical tendencies and suspicion of reason, see Montgomery Watt, Islamic Philosophy and Theology (Edinburgh: Edinburgh 
From this perspective, it is hardly surprising to encounter a Chechen disciple of Kunta Hājjī, the bringer of Qādiriyya Sufism to the Caucasus from Baghdad, express a political theology that (echoing Ahmad b. Hanbal's critique) criticized the excessively militant Naqshbandiyya Sufism active under Imām Shāmil's imamate. Drawing on the commonplace opposition between dunya and $\bar{a} k h i r a$, the goods of this world and the goods of the afterlife, Kunta Hājjī rejects the ways of the murìds, the followers of Imām Shāmil, in the conviction that the holy person does not rebel against an unjust regime, including Russian colonialism: 'Some have chosen the benefits of duny $\bar{a}$, others have chosen $\bar{a} k h i r a$, and others did not make a choice... [God said] "I promise to divide you into two groups: one group will be guides in dunya and others will be leaders in $\bar{a}$ khira... The first of the two groups are the murids ... [who] will not be directed to the happiness of akhira. Those who have chosen the benefits of dunyā will not find happiness in ākhira." "30 If Kunta Hajjī's Qadiri quietism has deep roots in the Islamic jurisprudential tradition, it follows that the 'new' Pankisi Islam should not be understood purely as an errant innovation. Caucasian Wahhabism can only be opposed to tașawwuf at the cost of ignoring Islamic history.

The Wahhabi movement and the new Islam in Pankisi share in common a return to a simple lifestyle and a monotheistic religious orientation. Although they share important features, their common foundations are hardly congruent with the assumption prevalent in current scholarship of categorical isomorphism. As shown above, north Caucasian Sufism is not necessarily pacifistic. Daghestani Sufism in particular has stimulated anti-colonial resistance and is as if not more influential politically than Kunta Hājjī’s quietism. At the same time, the Qādiriyya tariqa has provided the Kists with a powerful means for keeping religion alive during times of Soviet-enforced official atheism. The Naqshbandiyya and Qādiriyya represent two distinct paths for actualizing Islam's social imperatives and enable the north Caucasian Muslims to accommodate even Wahhabism within their belief systems. Through this accommodation, Wahhabism's internal structure has changed, resulting in a new merger, and a new Caucasian Islam. Let us now proceed to explore some of the concrete modalities through which Pankisi's Islamic landscape is becoming localized.

University Press, 1962) 120, 130; Ahmet T. Karamustafa, Sufism: The Formative Period (Edinburgh: Edinburgh University Press, 2007), 22.

${ }^{30}$ Cited from the unpublished and untitled manuscript of 'Abd al-Salām, a disciple of Kunta Hājjīi, (i. xii) in Anna Zelkina, 'Some Aspects of the Teaching of Kunta Hâjjî̀: On the Basis of the Manuscript by 'Abd al-Salâm Written in 1862 AD', Journal of the History of Sufism, 1/2 (2000): 483-508, at 492. 


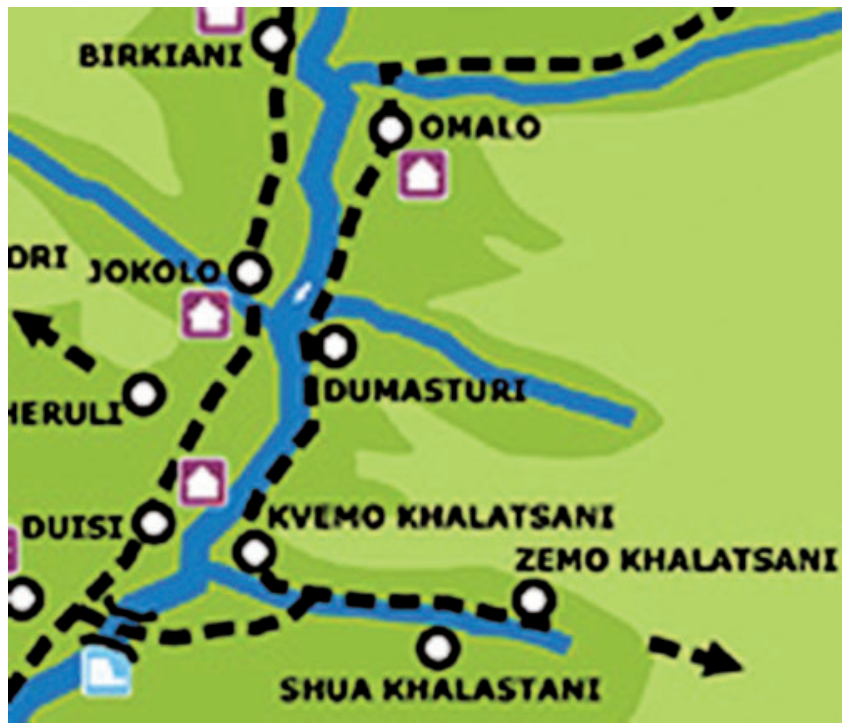

Fig. 3: Map: Pankisi Gorge, showing paths from Duisi to Jokolo to Omalo.

\section{PUBLIC WORSHIP}

I had just arrived in Omalo, the northernmost village in the Gorge (see map, Fig. 3), when a voice resounded from above, not far away, reciting the Qur'ān through a forest of trees. It was a dark night. The week-long power outage showed no signs of relenting. The absence of light made the voice resound all the more strongly. 'What is that?' I asked my host Rostom and his wife Mzia, though I could have answered myself: the call to the maghrib prayer from the minaret not far away (Fig. 4).

Constructed in the image of Duisi's minaret without the latter's colourful exterior which reminded all Duiselians of their Islamic identity, it had been erected less than a year before. The instigators for this building project were Chechen refugees resident in Pankisi since the beginning of the Second Chechen War in 2000. The refugees had saved money for the initiative until they found a sponsor who agreed to match their funds. The minaret towered over every other structure in Omalo, including the ancient towers distantly visible on the mountainous horizon. Everyone in Omalo had an opinion to offer on the aesthetic merits and demerits of the new minaret: some thought the concrete walls an eyesore, others deemed the grey slabs sublime, others regarded it simply as a curiosity. For all three constituencies, Omalo's minaret had 


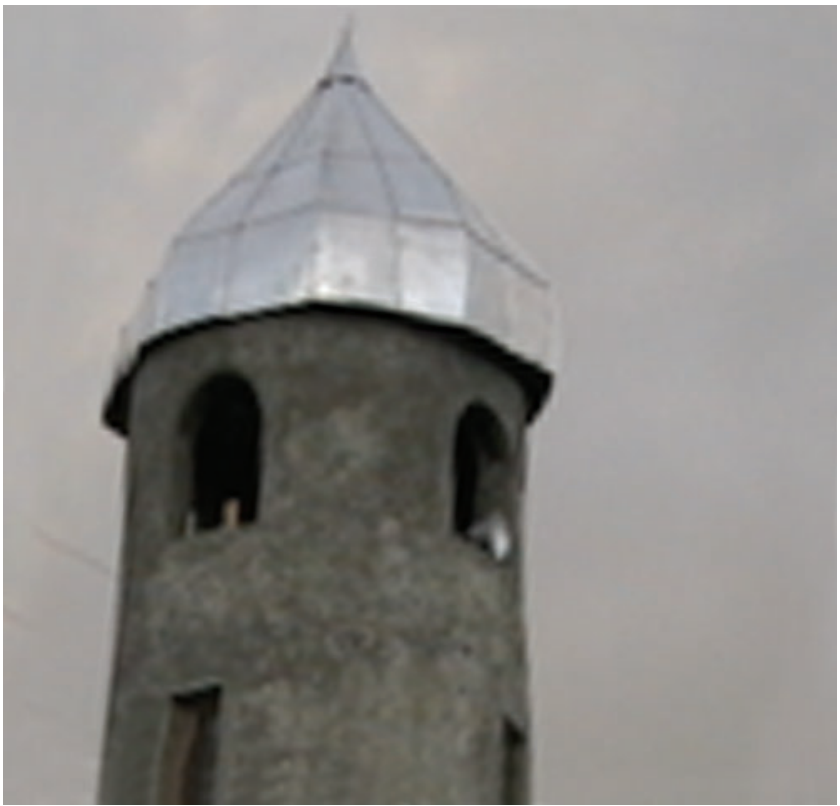

Fig. 4: Newly-constructed minaret in Omalo. ${ }^{31}$

fast become a fixture of the Pankisi landscape they could never have envisioned during the years of Soviet rule.

'Ever since the refugees came five years ago, they started the adhān [call to prayer]', Rostom explained. 'It's not a real voice, you know. They recorded the prayer on tape, and now they broadcast it five times a day, the fools.'

His wife contradicted him: 'No, it's a real person. The muezzin rises to the top of the minaret five times a day. I've seen him with my own eyes.'

'Not at all! They taped the prayer to a microphone and now they play it and perform all day.'

The argument continued into the night, as there was no other way to pass the time in the absence of electricity than by pushing this joke to the limit. More was concealed in Rostom's words than was evident to me when I first heard them. His dismissal of the Islamic symbol of worship resonated against the background of one of the best Soviet educations available in his milieu, and decades of intellectual training in the virtues of atheism and the irrelevance of belief. Rostom's mockery was directed

31 This photograph and those shown in Figs. 5, 6, and 9-14 were taken by the author, during fieldwork in Pankisi from June 2005 to August 2006. 
not merely against the Chechen refugees' non-secularity; more crucial was his scepticism concerning the intellectual validity of belief.

A professor affiliated with the Arnold Chikobava Institute of Sciences in the Georgian Academy of Sciences, Rostom was the most educated Kist in his village, one of a handful of Kists from Pankisi to be granted the degree doktor nauk, equivalent to the German Habilitation. He was respected within and outside the Academy as a specialist on the famously abstruse Chechen verb, and had recently published the first ever Georgian-Chechen dictionary. ${ }^{32}$ Rostom was also distinguished among Kist scholars for his humility. Rostom's contempt for religion did not conceal an unexpressed conviction in atheism's superiority, nor was it an unreflective prejudice derived from an elitist education. Like most secular curriculums, the Soviet system had provided Rostom with no vocabulary for describing religious experience; he had to rely on his own intellectual resources. As a linguist, he was accustomed to view humanity through the lens of science, and modern science, as he learned from the university, could not accommodate unreasoning modes of worship. So the call to prayer was an act of stupidity, and the desire to formalize ritual through mechanical means was further evidence of the absurdity of religious belief.

On another occasion, Rostom and I were headed home, when the dirt road along which we were walking filled with the sound of chanting. The sound streamed onto the street from the largest and best-maintained house in Omalo, which fronted the road that ran through the Gorge. The house's exterior was newly whitewashed and the walls of the room facing the street were made of tinted glass. Rostom was not pleased by the chanting that reverberated from the walls, this time in Chechen, unlike the mechanized recitative in Arabic that resounded from Omalo's minaret.

'Why do they blast those speakers so loudly, for all of Omalo to hear? Why can't they let us worship our gods in private? Why do they try to force their religion on us?'

I learned from further conversations with Rostom and his relatives that the Pankisi landscape had been empty of minarets until the influx of refugees, who brought with them the new Islam from Chechnya. (No one mentioned Duisi's minaret, built a century earlier.) And yet, if this was Wahhabism, it was a Wahhabism radically unlike any known before. This Wahhabism did not oppose itself to tașawwuf, but rather sought to revive it in a space where religious worship had until recently been

${ }^{32}$ Rostom P'areulizde, Nokhchiün-gu'rzhiı̆n dosham; Chechnur-k'art'uli lek'sikoni [Chechen-Georgian dictionary] (T'bilisi: Georgian Academy of Sciences, 2003). 


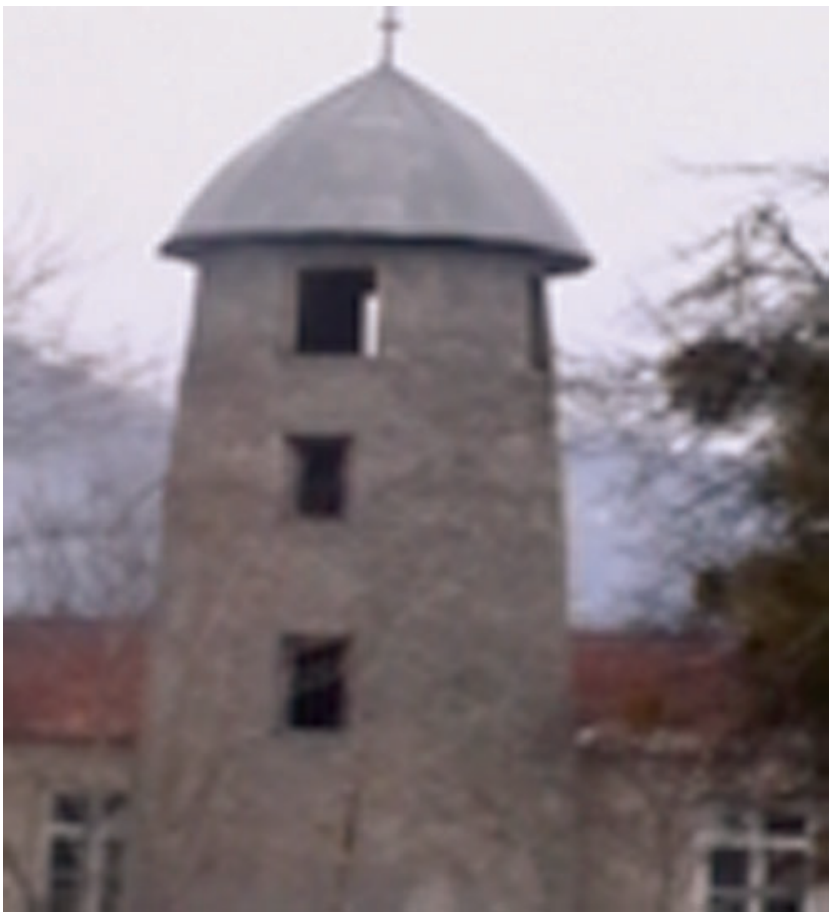

Fig. 5: Minaret in the neighbouring village of Birkiani.

forbidden. One of Rostom's nephews had gone over to the side of the 'new Islam'. In practice this meant that he was stricter than the rest of his family in his dietary habits, refusing all forms of alcohol and tobacco, fasted with precision on every holy day, prayed five times a day at a minimum, and had a better, if still imperfect, knowledge of the Qur'ān. The Christian churches from the past century were left standing and treated as holy places even by the new Wahhabis, although, as during the Soviet era, they remained empty. ${ }^{33}$

Unlike Rostom, many Kists were grateful for the influx of new Islamic currents from Daghestan to the north. The new Islam had brought with it greater peace and stability among the young generation, one mother explained to me. Even the new minarets were regarded fondly by some

33 On abandoned Georgian churches in Pankisi, see Paul Manning, 'Materiality and Cosmology: Old Georgian Churches as Sacred, Sublime, and Secular Objects', Ethnos, 73/3 (2008): 327-60. 


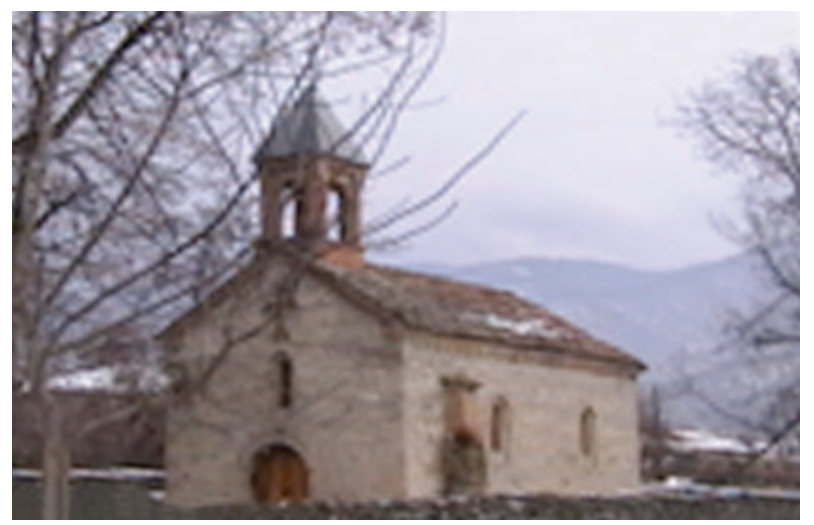

Fig. 6: Contemporary photo of St. Giorgi Church in Joqolo (also pictured in Fig. 1), a bathhouse during Soviet times.

Kists, though not by the majority. Rostom called them grey eyesores. His nephew compared them to the walls protecting a holy city.

'They are one proof that Pankisi is different from the rest of Georgia', Rostom's nephew explained one evening after dinner. 'Even though we speak Georgian with you, and even though we attend Georgian schools, so long as we have our own minarets, we won't forget our identity.'

To a greater extent than their fellow Vainakh, the Chechens and Ingush to the north, Kist attitudes towards religion are influenced, like their ritual practices, by Georgian Orthodox Christianity. Only rarely does this influence amount to wholesale assimilation to Christian norms. More than any other village in Pankisi, Joqolo had approached most closely to complete assimilation, particularly in the pre-Soviet period, when the benefits of conversion to Christianity were greater than during the Soviet and post-Soviet periods. St. Giorgi's Church still stands in the centre of the village (Fig. 6). It was built in 1866, soon after the first Chechen migration into Pankisi, but now stands empty. One of Georgia's most active and prolific Kists, Mat'e Albut'ashvili (18631953; Figs. 7, 8), served as a priest in St. Giorgi's Church during the decades that he penned his ambitious survey of the Pankisi landscape. First published serially, Albut'ashvili's essays on Pankisi were later collected under a title-The Pankisi Gorge: A Historical-Ethnographic and Geographical Description (Pankisis xeoba: istoriul-etnograpiuli da geograpiuli aghtsera, 1898)—that may have been intended to evoke comparison with the Geographical Description of Georgia (Sak'art'velos istoriul-geograpiul aghtsera) by the Georgian Prince Vaxusti (d. 1772), a text that monumentally placed Georgia on the map of world 


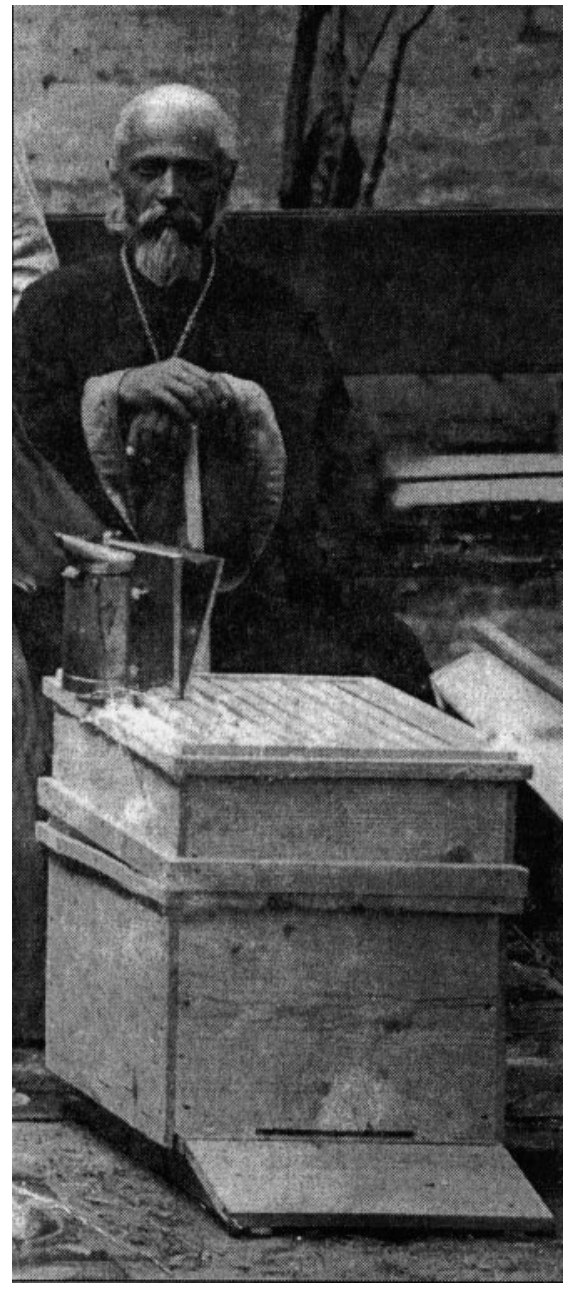

Fig. 7: Mat'e Albut'ashvili, 1916.

historiography. After Albut'ashvili's death, St. Giorgi's Church was turned into a bathhouse (abano), a familiar Soviet gesture, laden with the symbolism of sacrilege. ${ }^{34}$

${ }^{34}$ A more famous example of the Soviet endeavour to desacralize the sacred is the conversion of St. Isaac's Cathedral in St Petersburg into the 'Museum of Religion and Atheism' during the most oppressive years of Stalin's rule (1930-37). 


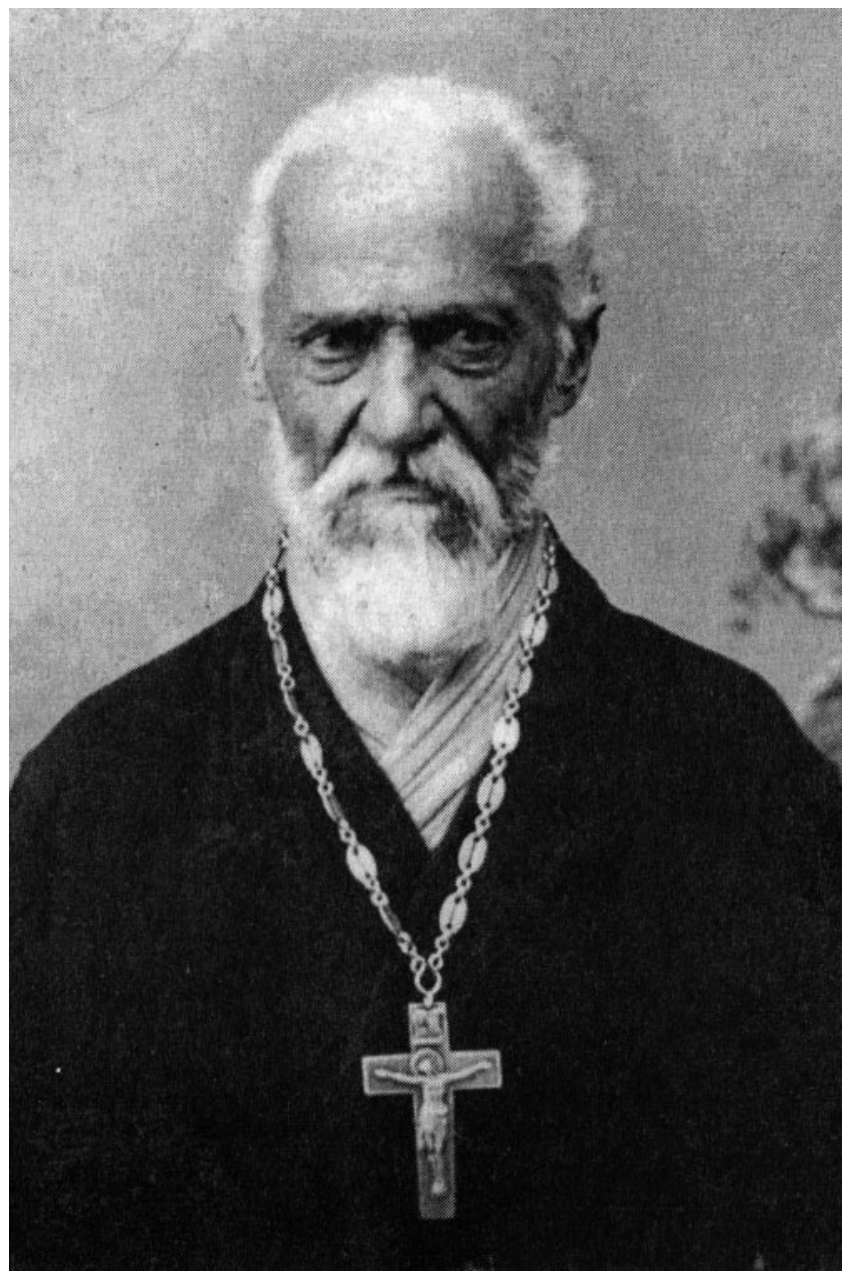

Fig. 8: Mat'e Albut'ashvili, 1940.

\section{PUBLIC MOURNING}

Having focused on the architecture of Pankisi worship through minarets and churches, I now turn briefly to another aspect of Pankisi Islam which conveys the emotive needs of Kists and Chechens, namely burial rituals, headstones, and related practices for dealing with mortality. If minarets teach us about the new developments in Pankisi religiosity over the course of the past decade, burial practices reveal even more about 
vernacular Islam on its northern periphery. Just as the adhān issued from minarets raises tensions at the dinner table and between generations in Pankisi, so do burial practices induce silence when the subject is raised in public contexts. The burial rituals that have been in place for centuries have recently come under challenge by the new generation of Muslims, who regard practices such as inscribing the face of the deceased on his or her headstone as shirk. And yet both the old and young generations agree in setting aside separate rows in their cemeteries for commemorating the shuhadā (sing. shahīd) who died in the recent Russo-Chechen wars.

Many graves in the old cemeteries of Joqolo and Omalo bear marks of Christian influence: crosses etched on headstones, and carefully carved images reproducing the deceased's likeness. Such practices contrast with the customs of Sunni Daghestani Muslims in the nearby village of Satslis Xure in Khakheti in northeast Georgia. Similar gravestones may be found in Baku's Şəhidlər Xiyabanı (Gallery of Martyrs in the NagornoKarabakh war), suggesting in this instance-although the practice of including an image of the deceased on headstones is attested elsewhere in the Muslim post-Soviet world-how, as locals explained to me, Pankisi Kist custom amalgamates Azeri Shi'a practices with Georgian Christianity. Another striking aspect of Pankisi's Muslim cemeteries is inclusion of the $d \bar{u}^{c} \bar{a}$ (prayer or farewell invocation) in Georgian rather than Arabic script (Fig. 9).

The old-style headstones contrast strikingly with the new headstones created to honour the young Chechens from Pankisi who died in the war. Buried in the old cemetery in Duisi, a kilometre south of Joqolo, this more traditional cemetery (Figs. 10 and 11) offers more room between headstones and subordinates their organization to a different order. The headstones are all in Arabic script, and, with the exception of a faintly etched head, there are no anthropomorphic images to be seen. Some headstones are more elaborate than others, but all are austere compared to Joqolo's headstones.

Most moving of all the headstones is one in the corner of Duisi's version of Baku's Şəhidlər Xiyabanı (Gallery of Martyrs): two rows of roughly twenty empty graves, each nameless headstone marking a young Chechen who died in the recent war. At the end of the first row, one headstone in particular arrests the gaze. It is pallid grey, with no flourishes, and inscribed with only two words in Chechen: dik k1ant, meaning good boy, a commonly recurring phrase in Chechen epic tales (illi). This epithet is given, unusually, in Georgian script. A green headband is wrapped around the top, green being the colour both of martyrdom and of piety in Islam. Duisi's row of martyrs evokes comparison with the headstones on the martyrs' graves in Khasav-Yurt, a city formerly inhabited by Chechens, now part of Daghestan. Due to its 


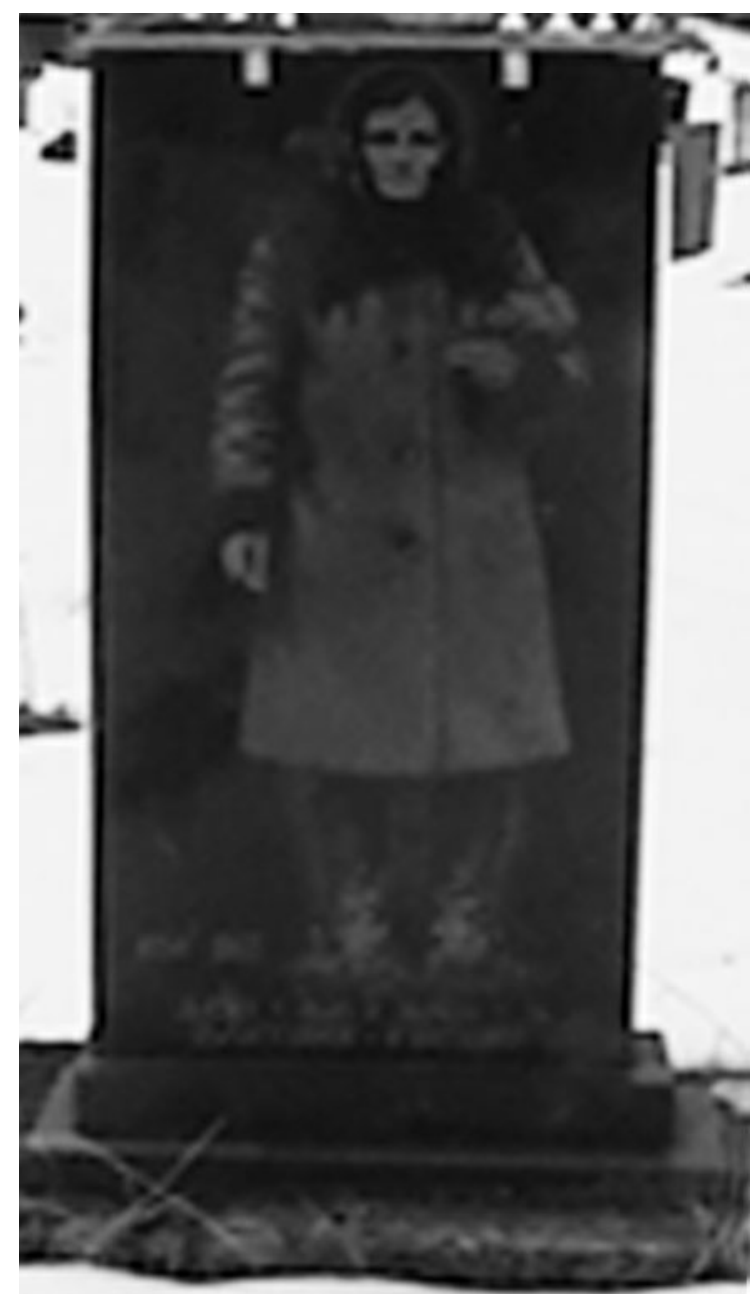

Fig. 9: Headstone of Kist woman, Joqolo's new cemetery.

location in the heart of the north Caucasus, Khasav-Yurt has had more continuous contact with Islamic norms and rituals than Pankisi. This difference is apparent in the comparatively more elaborate headstone that marks the graves of fallen shuhadā in Khasav-Yurt (Fig. 14). In the latter locale, each shahid's grave is topped by an elaborate green banner and a crescent moon with a star.

The blurred boundaries Pankisi straddles between Islam and Christianity, and which are reflected in their headstones as much as in 


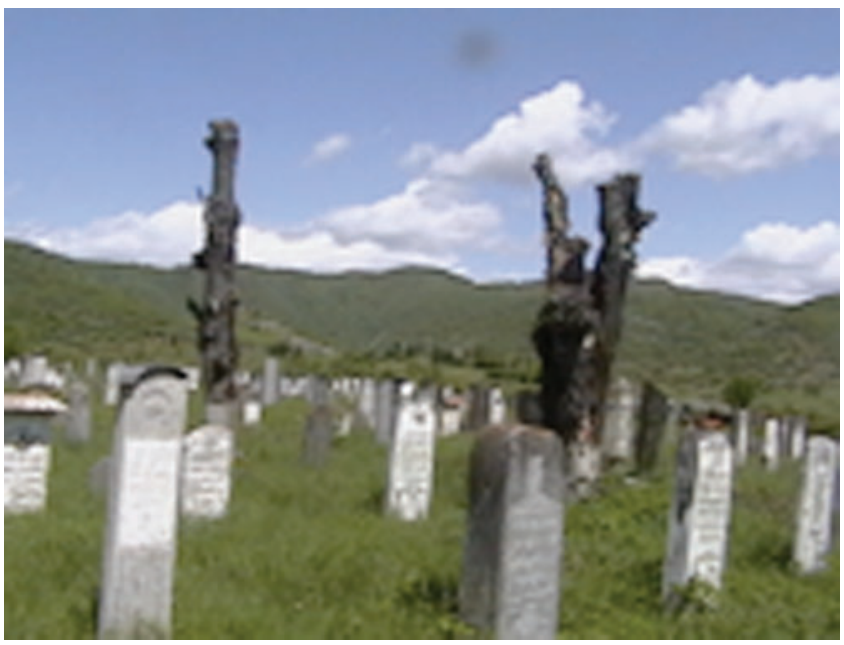

Fig. 10: Duisi cemetery.

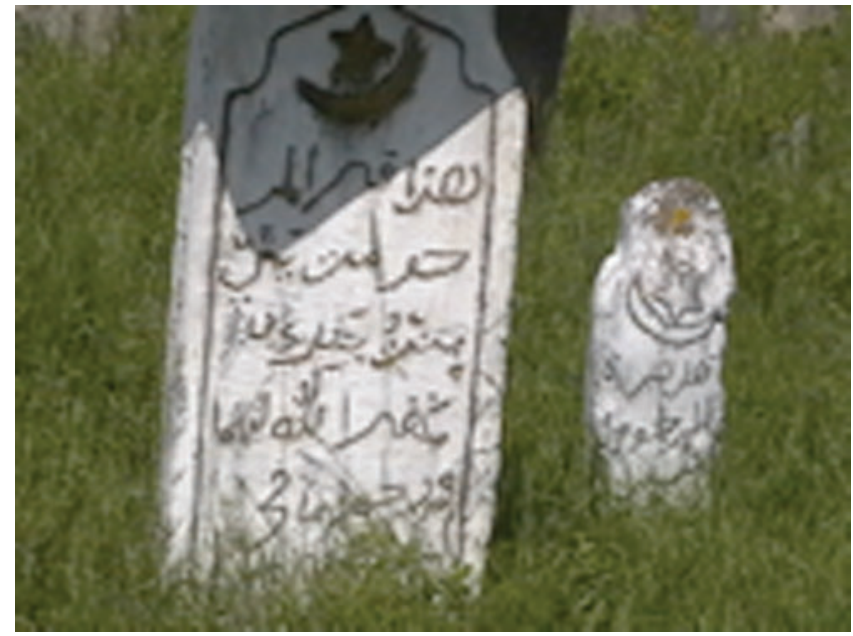

Fig. 11: Traditional Sunni headstone.

the proximity of churches and minarets, do not disturb most Kists, even though they identify as Muslim with near unanimity. Perhaps due in part to their location on the Chechen-Georgian border, the Kists are adept at managing multiple identities. Like the Chechens, their interest lies more in self-preservation than in adhering to external standards of religiosity. In this respect, Kist religiosity is a product of what Taylor has famously 


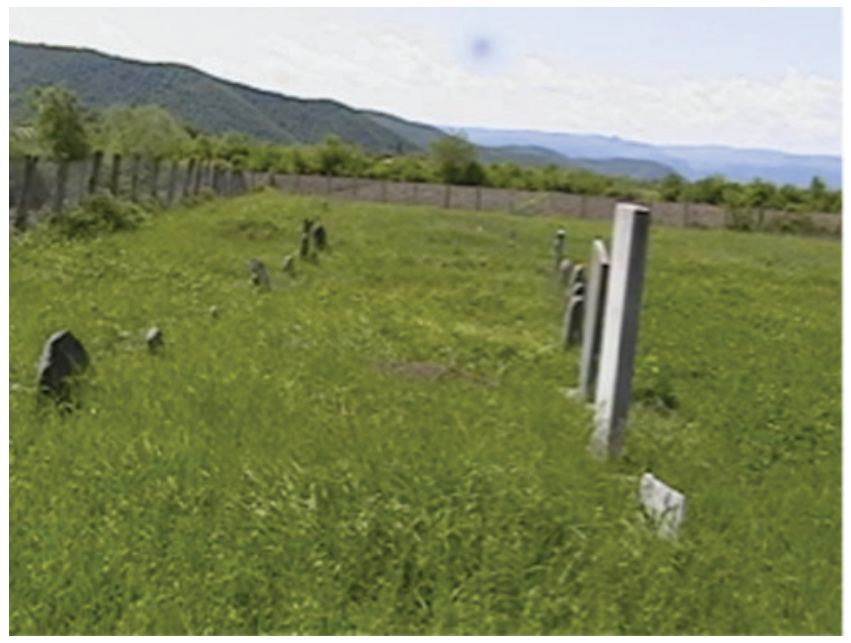

Fig. 12: Gallery of Martyrs, Duisi cemetery.

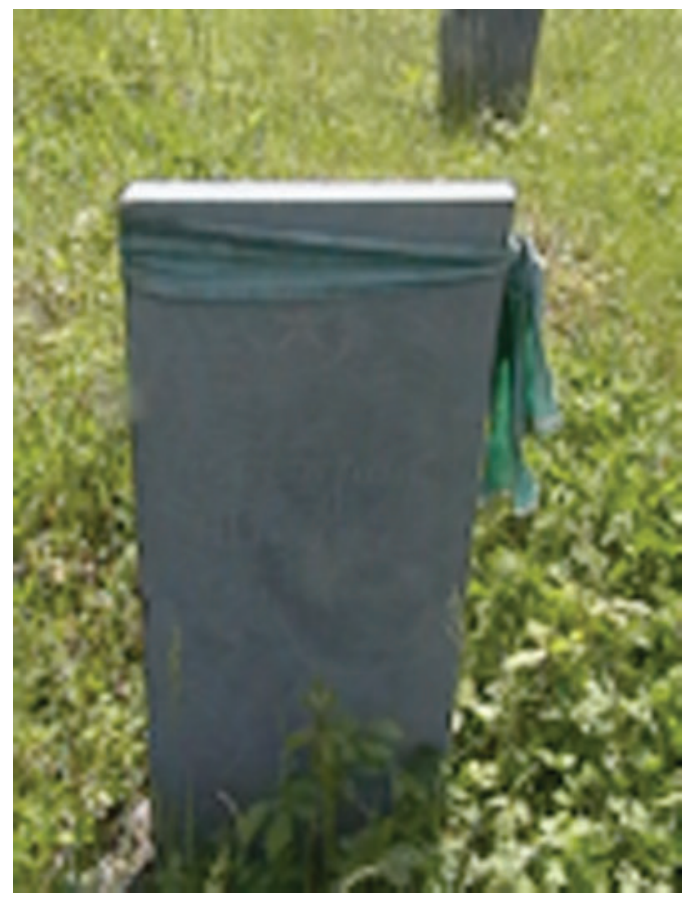

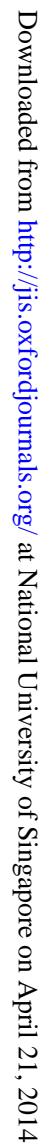

Fig. 13: Shahid's headstone, Duisi cemetery. 


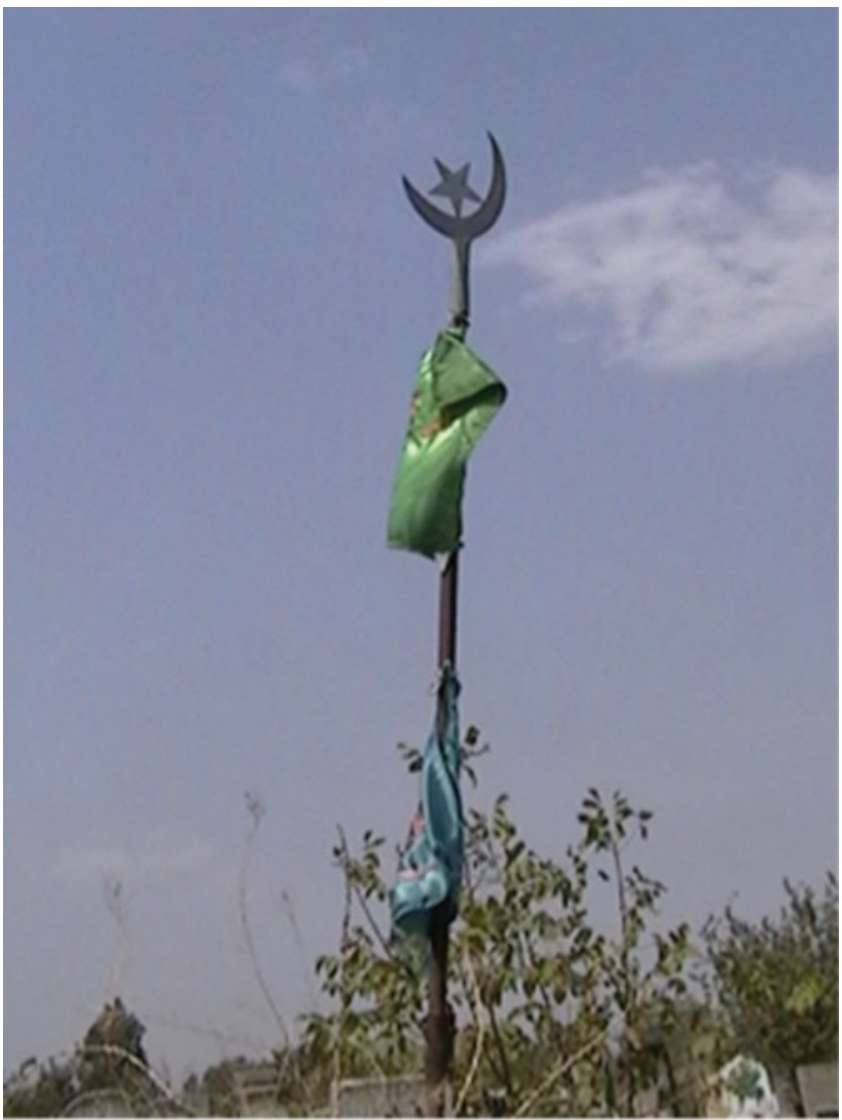

Fig. 14: Central cemetery, Khasav-Yurt, Daghestan.

called a 'secular age' in which 'being a citizen takes precedence over a host of other poles of identity, such as family, class, gender, even (perhaps especially) religion'. ${ }^{35}$ As one Kist explained: 'Headstones and minarets

35 Charles Taylor, 'The Secular Imperative' in Rajeev Bhargava (ed.), Secularism and Its Critics (Delhi: Oxford University Press, 1998), 44. In elaborating on this condition, Charles Taylor argues that the replacement of religiosity by citizenship 'may be promoted in a deliberate way, on the basis of an express ideology, as in the case of French Republicanism. Or it may be fostered in more indirect ways, as a consequence of the injunction to render other modes of description-gender, race, religion, etc.-irrelevant in the operation of public life'. While Russia's policy in Chechnya is an example of the former mode, Georgia's influence in Pankisi exemplifies the latter. 
come and go. The styles change with every generation. But the Kists will always be here. We don't change ourselves as easily as we change our religions.'

Kist women are more forthcoming than Kist men in describing their ritual practices. Rostom's wife Mzia told me about a wird (sect) of Duisielians in whose gatherings she sometimes participated. Although the dichotomy is not uniform across the Islamic world, Naqshbandiyya orders in the Caucasus perform al-dhikr al-khafī (silent recollection of God), whereas the Qādiriyya orders to which most of Pankisi's devout Muslims among the older generations belong perform al-dhikr al-jahri (loud recollection of God). The Duisi wird is no exception; their only distinctive quality is that they perform the dhikr al-jahri on their knees in complete darkness. Mzia further informed me that the shaykh of the Duisi wird is buried in the village of Karbala on Georgian territory, near the Azeri border. As the village name suggests, Karbala is populated by Shi'a Azeris. Kists who belong to this wird visit their shaykh's grave regularly. According to Mzia, their rituals draw heavily on Shi'a practices. Although the followers of this wird do not consider themselves Shi' a, perhaps, Rostom suggested as he joined our conversation, they are Shi'a in origin. As we speculated more on the subject, Rostom's interest seemed to increase, until finally he interrupted:

'Isn't it strange how everyone believes the same thing yet they try to present it as their own truth? All that separates the Duisi wird from the Shi'a is a label. Why don't they just call themselves Shi'a?'

Mzia added that there is a second wird in Pankisi, the Hājjī wird. As Mzia's mother had belonged to the Shaykh wird, she was relatively ignorant of Hâjjī wird rituals, and advised me to ask other elderly women for more information. But no one in Omalo seemed to know who the Hājjī pilgrimage to Makka-in question was. Concluding that she was better informed about the original Pankisi Islam than anyone else in Omalo, I returned to Mzia:

'Was there actually someone who went on the hajj from Pankisi?' I asked. 'Is that why they call themselves Hàjjī? Does anyone travel from here to Makka?'

Mzia explained that the hajj had been quite common in pre-Soviet days, especially for men, but also for Kist women. It had been forbidden during Soviet rule. Now, Kists were returning to old ways. Over ten of Pankisi's elderly generation had performed the hajj in the past year. According to some of Rostom's cousins who had arrived in Pankisi as refugees from Chechnya, a shrine still stood in Vedeno, high in mountainous Chechnya where even Russian soldiers rarely travelled. The mother of the founder of the Hâjjī wird was buried there. Her name was 
Patimat, a Georgianized form of Fātima (lacking an equivalent for $f \bar{a}^{\vec{\prime}}$ in its alphabet, Georgian assimilates $f$ to $p$ ). I mentioned that Vedeno, in addition to being a base for Imām Shāmil's imamate and the birthplace of Shāmil Basaev, was the burial place of the abrek (holy bandit) Zelimkhan (d. 1913), who famously staged one of the final resistances to Russian rule before the north Caucasus was incorporated into the Soviet empire. ${ }^{36}$ These connections suggested that the Hājjī wird originally had deeper ties to militant Naqshbandiyya Sufism than Qādiriyya quietism.

\section{SOVIET SCEPTICISM}

Rostom used Mzia's description of religious practices in Pankisi as a pretext for another parody of the ridiculous antics people stoop to for the sake of their belief in God.

'Just think of the silliness that fills the world,' he said. 'Think of all the money wasted on building temples, when we could just as easily pray at home. Those new Muslims try telling us that we have to pray in Arabic! Does God only understand one language?'

But the real mocker of religion in Pankisi was not Rostom, whose circumspect nature prevented him from crossing the bounds of respect for what he couldn't appreciate, but Suleiman Gumashvili, poet, scholar, and heretic extraordinaire. Suleiman had lost his job in the Saakashvili administration following the Rose Revolution (2003) for his antiGeorgian and pro-Kist statements, and now he was intent on stirring trouble at home. ${ }^{37}$

'You know what the Bible is?' Suleiman asked me once, after spending two hours explaining how Christianity and Jesus Christ himself were derived from the Vainakh people. 'It is a collection of fairy tales and lies. Some smart people centuries ago sat down to write a book to fool the rest of the world. And they succeeded! Christianity is nothing more than a myth.'

One evening, as I sat talking to Suleiman while he finished his third shot of vodka, I asked if he considered himself Muslim. Given his previous dismissive and deliberately provocative comments concerning the Qur'ān, I expected him to say no. 'Of course,' he announced without irony, as he downed the shot of vodka and poured another. 'I may not

${ }^{36}$ For a detailed account of the complex genealogy and legacy of Zelimkhan and other abreks, see Rebecca Gould, 'Transgressive Sanctity: The Abrek in Chechen Culture', Kritika: Explorations in Russian and Eurasian History, 8/2 (2007): 271-306, and the accompanying bibliography.

37 Suleiman's work and beliefs are discussed in detail in Gould, 'Language Dreamers'. 
believe in all the Muslims say, I may not always pray at the right times, but I am definitely Muslim.' In laying claim to a Muslim identity that did not require full assent to Islamic doctrines or participation in ritual injunctions, Suleiman suggested that Khalid's argument that 'before the Russian conquest... being Muslim meant [only] being part of a community that saw itself as Muslim' obtains today in certain circles, long after the fall of the Soviet Union. ${ }^{38}$ Even more profoundly, it attests to what we have called the secularity of post-Soviet Islam, whereby the abstracted category of religion is taken to produce 'certain particular and predictable effects', be they positive or negative. ${ }^{39}$ This characteristically modern form of secularism identified by Casanova as one of the few overdetermining features of our global condition does not presuppose antagonism towards religion, as is sometimes assumed in Euro-American contexts. It does however subordinate religious to cultural and political ends even-perhaps especially-when it does so within an explicitly Muslim framework.

Other self-identifying Muslims in Pankisi suggest just how much has changed since the days when being Muslim was primarily a cultural and even ethnic identity. When I conducted my interviews with Suleiman during the day, his fourteen-year old son Zelimkhan sat in a corner, curled over a book, whispering to himself quietly. At first the content of Zelimkhan's whispering was unclear. Unaccustomed to such practices among the Kists, I suspected he was reciting a text in a foreign language. One day, I entered unannounced, not knowing he was present in the corner, silently reciting. Zelimkhan stopped his recitation. We sat together in silence, awkwardly, until I moved to the other room. It did not take long for me to realize that he was reciting the Qur'an, though this was the last thing one would expect from a son of Suleiman. Zelimkhan's sister Patima was less secretive about her brother's religious loyalties, perhaps because she did not interpret Suleiman's criticisms of Islam as personal affronts. When Zelimkhan's elder brother visited Joqolo a week later from Grozny, his character seemed to change entirely. No longer was he the shy boy reciting the Qur'ann secretly. In the presence of an elder brother who felt no need to be apologetic about his religious identity, and who regarded his experience in war as proof of his piety, Zelimkhan began to take on the characteristics of his brother. His recitations of the Qur' ān suddenly increased in frequency, as did the

${ }^{38}$ Khalid, Islam after Communism, 21.

39 Jose Casanova 'The Secular and Secularisms', Social Research 76/4 (2009): 1049-66, at 1052. Also see Talal Asad, Genealogies of Religion (Baltimore: Johns Hopkins University Press, 1993). 
pitch of his tajwid (recitation). Suleiman was not pleased by these changes, but, as there was nothing he could do-or wished to do-to stop his Zelimkhan from imbibing this new milieu, he took the new influence which his eldest son exerted on his youngest son, as he did everything else, in his stride, and made of his son's newly emergent character an archive for jokes.

'My sons don't like it when I drink', Suleiman explained once his sons were out of hearing range. 'They tell me it's written in the Qur'àn that drinking is forbidden. No gambling or drinking-al-khamr wa-l-maysir, they call it-in the house of Islam. I ask them: What is the Qur'ann but a collection of fairy tales? They don't like my answer, and so we fight all the time.'

Suleiman's exposure to the ambiguities of religious life in a society that officially mandated atheism among the educated classes enabled what from other perspectives would seem like a contradiction: Suleiman called himself Muslim, especially when faced with an alien Christian creed, and when asked to define himself to the outside world. But when ensconced in his own home, in Pankisi, he became the inverse of his public identity. By his sons, and to a lesser extent by his neighbours, Suleiman was regarded as a heretic and practitioner of shirk. In response, he denied the validity of pillars of the Islamic faith including the Qur'an-hardly a common response for the pious Muslim he insisted on being in Georgian contexts.

One day, Suleiman took me on a tour of Joqolo. We passed St. Giorgi's church, one of the village's central landmarks, once flourishing but now solemnly standing empty, a remnant of religious practices that had been overcome. When we reached the town centre, we approached a group of men leaning against the dilapidated central office (called in Georgian sabcho), the closest thing Joqolo had to a city hall.

'Meet the two mullahs of Joqolo,' Suleiman said in his customarily mocking tone. 'One is Wahhabi-' he paused and pointed to a young man in running pants with rolled up cuffs and dirty tennis shoes-'the other is Harabi.' He pointed to an elderly man in the traditional accoutrement of the north Caucasian highlander, papakh (a tall hat made of wool) and chokha (a thick cape made of animal skin).

The men entered into a debate regarding which language to speak in the presence of a foreigner: Kist (Chechen) or Georgian. This led to my questions concerning the extent of their knowledge of Arabic. It turned out that Suleiman the apostate knew Arabic best of all, or at least he was the only one willing to cite the 'Our Father' prayer from the Christian Bible in Arabic. After Suleiman finished reciting the prayer in Arabic, he turned to the 'Wahhabi' mullah and asked him to start praying in Arabic for my sake. 
Suleiman pointed to my camera and said I would capture it on film, that I had come all the way from America just to see him 'perform' the prayer. Vakha did not seem perturbed by Suleiman's blasphemy. I separated myself from the crowd and glanced in the direction of Suleiman's home, indicating that it was time to end these mockeries and go home. But Suleiman would not give up.

'Why won't you perform for her? She really wants to see a Chechen Wahhabi say a prayer in Arabic. Get down on your knees, man!' Though Suleiman spoke Georgian for my benefit, Vakha, annoyed by Suleiman's antics, reproached him in Kist.

Both Rostom and Suleiman enjoyed mocking religious pieties. Their religious scepticism marked both as Soviet-educated intelligents. For both intellectuals, religion seemed a farce, a stage on which the follies of the world played out. Their resistance to Islam was no less a performance than were the prayers to which I awoke every morning during my field work in Omalo. Their secularity was less anti-religious than the product of a new modern configuration of things, what Casanova calls 'an epistemic knowledge regime that may be [...] phenomenologically assumed as the taken-for-granted normal structure of modern reality, as a modern doxa, or as an "unthought". 40 As a Georgian friend once explained to me, anyone whose mind was formed during the Soviet era learned to ignore the first and last section of any book, because it was on these pages that the ideological content was most intense and where the most concessions were made to Soviet dictums. Only the sections between the beginning and the end, the sections that censors were too busy to inspect, were worth reading. This is how form became a matter of content and content became a matter of form under the Soviet regime.

This hermeneutic principle may help us to understand the relation between form and content in the study of Islam in post-Soviet spaces. The common vocabulary through which Rostom and Suleiman articulated their critique of the newly emergent faith of Pankisi Islam has been noted. For a textual exemplification of their arguments, we may turn to a foundational text in the Soviet historiography of Chechen Sufism, Iandarbek Iandarov's Sufism and the Ideology of National Liberation (1975). ${ }^{41}$ While this text was the first scholarly work to

40 Casanova, 'Secular and Secularisms', 1051.

${ }^{41}$ Iandarbek Iandarov, Sufizm i ideologiia natsional'no-osvoboditel'nogo dvizheniia: iz istorii razvitiia obshchestvennykh idei $v$ Checheno-Ingushetii $v$ 20-70-e gody XIX v. (Alma-Ata: Nauka, 1975). Iandarov's text is also important in Chechen historiography as it was one of the very few scholarly studies produced by a Chechen after Stalin's brutal deportation of the Chechens and many other Muslim peoples to Central Asia. That the work was published in 
examine with a relatively open mind the impact of Islam on north Caucasian anti-colonial movements, when the author undertakes to analyse the relationship between Imām Shāmil's murīd movement and the Naqshbandiyya Sufism which inspired it, the political conditions under which the secularized Vainakh intellectual laboured in Soviet times are exposed in all their strengths and limitations.

The book's subtitle points to its specific focus within the broader project of exploring Sufism's political implications: Towards a history of the political in Chechnya and Ingushetia from the 1820s to the 1870 s. ${ }^{42}$ This time span-the 1820 s to the 1870 s-frames the era of anti-colonial resistance to Russian conquests. ${ }^{43}$ Quotations from the early Marx are skilfully deployed to demonstrate a thesis that stands in striking tension with the author's own nuanced examinations of Sufism. For Iandarov, religion is a 'cover'-the term he uses is oblochka, meaning form, model, shell, or pretext-for social and political grabs for power. Iandarov's thesis of religion-as-form owes a deep, unwitting, debt to Christian theodicy, specifically to the pietistic version of it inherited by Marx. Far from being neatly opposed to religion, even the Soviet discourse on the sacred did not manage to suppress the problem of belief entirely.

At one level, Iandarov echoes the Soviet-enforced idealization of worlds without religion. At the same time, and in contradiction to the first premise, in arguing against one kind of Sufism, Iandarov's text argues for another. And while the contemporary reader is struck by the Soviet imprint of his thesis, more striking on closer inspection is the author's subversion of Soviet norms. Sufism and the Ideology of National Liberation provides a code for reading national liberation into tașawwuf. Iandarov's hermeneutic strategy reproduces Soviet conflations of nation, ideology, language and religion, but his method exceeds these reductions.

Under the guise of Marxist-Leninism, Iandarov critiques Tsarist sources for reducing religion to fanaticism. 'All official organs of the Tsarist era', he writes only a few years before Said's Orientalism (1978) made a related point in a different language and under radically different

Alma Ata, the capital of Kazhakhstan, where Iandarov had been deported, is highly significant.

${ }^{42}$ Many plausible translations for 'obshchestvennykh idei' could be proposed, including 'social ideas' and 'political ideas'. I have preferred to collapse the singular/plural distinction and simply translate the phrase by 'the political'.

${ }^{43}$ There was no such political entity as 'Chechnya-Ingushetia' during the nineteenth century. This is a Soviet invention (the Republic of ChechenoIngushetia was created in 1938, destroyed in 1944, and brought back to life in 1957, only to be destroyed again with the fall of the Soviet Union in 1991), so Iandarov's subtitle is anachronistic. 
political circumstances, 'represented the mountaineers as fanatics, and even their courage and the incredible sacrifices they displayed in their struggle for freedom, was explained only by fanaticism'. ${ }^{44}$ The Chechen-Soviet scholar uses the normative clichés of Soviet ideology as an obolochka within which to pursue a contrarian agenda, ultimately incompatible with the norms of the system within which he was writing. Soviet ideology made available to Iandarov a position from which to critique Tsarist colonialism. This subversive element in his writing is more significant than the formal concessions his texts make to Soviet ideology.

Iandarov's officially anti-religious, pro-Soviet stance did not prevent him from offering his own phenomenology of tașawwuf. 'Sufism,' he wrote, 'like religion in general, can only be born in a society in which, to use the words of Karl Marx, a person is intensely aware of the "uncertainty [samorazorvannost'] of earthly existence." In Sufism the fleetingness [neustroiennost'] of the world is expressed, as is the hostility of social institutions to human nature, and the impossibility of recreating the world [pereustroistva mira]. Such is the foundation for Sufism's advocacy of making peace with the world that exists, as well as its belief in the fleetingness of the world' ${ }^{45}$ Iandarov's rejection of pereustroistva mira, the task of recreating the world, flies directly in the face of Marxian precepts on the role of agency in history. When Soviet writers applied Marx mechanically, as they were often constrained to do, they often omitted the second premises of Marx's arguments. Thus the famous line from The Eighteenth Brumaire of Louis Napoleon (1852) 'Men make their own history [ibre eigene Geschichte], but they do not make it just as they please [aus freien Stücken]; they do not make it under circumstances chosen by themselves, but under circumstances directly encountered, given and transmitted from the past [überlieferten Umständen] ${ }^{46}$ was reduced to an argument for the autonomy of the acting subject in history, as was the even more famous cliché concerning religion as the opium of the people. Soviet scholars omitted that Marx had preceded his dismissal of religion with a more ambivalent claim, calling religion: 'the sigh of the oppressed [der Seufzer der bedrängten Kreatur], the heart of a heartless world [Gemüt einer herzlosen Welt], and the soul of soulless conditions [der Geist geistloser Zustände]'. ${ }^{47}$ In the aftermath of the Soviet

${ }^{44}$ Iandarov, Sufizm i ideologiia, 160.

45 Ibid, 46.

${ }^{46}$ Marx/Engels-Werke (Berlin: Dietz, 1971), viii. 115.

${ }^{47}$ Ibid, i. 378. Michel Foucault also criticized the Marxist left of his milieu for misunderstanding and misquoting Marx's critique of religion. See his Politics, 
experiment, these words hardly read as an injunction to banish religion from modern life.

By subverting one kind of Marxist-Leninist reading practice, Iandarov accessed another hermeneutic, derived from a Marx better known to Western theorists but hardly known at all, and in a fundamental sense, unknowable to the Soviet-educated intelligentsia. This was a Marx Iandarov perhaps had never read, and whom he certainly never learned about in school, but who nonetheless helped him to understand the peculiar persistence of Islam in the modern world. Sandwiched between the official disavowals of religion at the beginning and end of Iandarov's book is a cogent and sympathetic analysis of Sufism's philosophic origins. Marx's canonical voice sanctions a passage that would otherwise seem anti-Soviet and therefore a dangerous liability for the author. Tașawwuf in Iandarov's work represents the negation of the Soviet doctrine of the inevitable progress of human history.

\section{SECULARITY AS THE GENERATOR OF RELIGION}

Now that we have examined conceptual barriers erected by Christian, and following that, Soviet, paradigms, to belief, it remains to make sense of religion's persuasive power in the desacralized spaces of Pankisi's shrines, cemeteries, mosques, and abandoned churches. Surely these new Islamic currents do not represent the last gasp of a dying faith. More is at stake in the controversies over minarets in Pankisi and Switzerland, over headscarves in France, and even over cartoons in Denmark. Casanova registers this point well when, in reflecting on the secular condition, he notes that the fact that the 'modernization of so many non-Western societies is accompanied by processes of religious revival should put into question the premise that the decline of religious beliefs and practices is a quasi-natural consequence of processes of modernization'. ${ }^{48}$ The most peculiar point that emerges from the ethnography adduced above is that the religious revival that has in part been documented here is not merely compatible with the persistence of the secular but is in fact its direct consequence. More visibly in Pankisi than elsewhere in the world, secularity produces religion, and does not simply or solely negate it.

Philosophy, Culture: Interviews and Other Writings, 1977-1984 (ed. Lawrence

D. Kritzman and Alan Sheridan; New York: Routledge, 1988), 218.

${ }^{48}$ Casanova, 'Secular and Secularisms', 1053. 
In his critique of the secular, Gil Anidjar has written that 'Islam is to Europe... [what] religion is to secularism'. ${ }^{49}$ On Anidjar's reading, Islam's failing from the point of the view of the Euro-American mainstream, is that unlike Christianity, it has failed to 'secularize itself'. Orientalism in this elaboration has historically served as the handmaiden of this division. 'Orientalism-that is to say, secularism-', writes Anidjar, 'became one of the essential means by which Christianity failed to criticize itself, the means by which Christianity forgot and forgave itself'. ${ }^{50}$ In a different through related vein, Marcel Gauchet has captured the uniqueness of the Christian dispensation in world history by characterizing it as 'a religion for departing from religion. ${ }^{51}$ An even fuller articulation of Christianity's specific contribution to the secular is proposed by Casanova, who argues that the secular first emerged as a Christian theological category 'that not only served to organize the particular social formation of Western Christendom, but structured thereafter the very dynamics of how to transform or free oneself from such a system,. ${ }^{52}$ The combined insights of Casanova, Gauchet, and Anidjar tell us that in creating the secular, Christianity inaugurated the end of religion.

And yet, as Casanova would be the first to point out, our conception of the potential forms taken by the secular should not be wholly circumscribed by the Christian tradition, no matter how crucial this tradition may be to making sense of our global modernity. A strong case can be made that Islam, precisely in its capacity as a religion, can contribute to a deeper and more wide-reaching understanding of the relations between the sacred and the profane, the transcendent and the immanent, and the secular and the religious. ${ }^{53}$ Casanova is right to point out that, notwithstanding their seeming parallelism, the binaries that structure secular and non-secular relations do not coincide, and every tradition has a different perspective to add. In Pankisi, where the adhān is welcomed in a landscape that has yet to shed its Soviet inheritance, secularity has contributed to the flourishing of religion. The coexistence of these supposed antinomies-secularism and religion-suggests the fallacious logic that motivates certain reductionist applications of the secular premise. Secularism has not succeeded in killing the gods though in many cases it has lost the ability to cope with them.

${ }^{49}$ Gil Anidjar, 'Secularism', 75.

${ }^{50}$ Ibid, 63.

${ }^{51}$ Marcel Gauchet, The Disenchantment of the World: A Political History of Religion (Princeton: Princeton University Press, 1997), 4.

${ }_{52}^{52}$ Casanova, 'Secular and Secularisms', 1063.

${ }^{53} \mathrm{Ibid}$. 
If we distinguish between secularism as ideology-the doctrine that consciously opposes itself to religion and which presents this opposition as the only intellectual valid option-and secularism as statecraftwhich makes provision for the free exercise of religion and the free exercise of church and state-then the argument can and has been made that Islam actively propagates the secular through its political arrangements, albeit in radically different fashion from the Christian dispensation. ${ }^{54}$ Far from being a paradox, the persistence of Islam in Pankisi would appear to be the logical outcome of nearly a century of secular rule. In making possible 'a less Eurocentric comparative analysis of patterns of differentiation and secularization, ${ }^{55}$ and thereby learning to conceive the secular in ways we have not been taught to do before, an anthropology of Islam will help us understand the religious structure that informs the secular even as we come to grips with the secular content of modern religion.

${ }^{54}$ For example, Abdullah Ahmed an-Na $\mathrm{im}$ argues that a truly Islamic state can only be a secular state, and that Shar ìa is incompatible with theocracy. See his Islam and the Secular State: Negotiating the Future of Shari a (Cambridge: Harvard University Press, 2008).

55 Casanova, 'Secular and Secularisms', 1050. 